\title{
The impact of systemic factors on the deployment of cooperative projects within renewable electricity production - An international comparison
}

\author{
Ingrid Mignon and Andreas Rüdinger
}

Linköping University Post Print

\section{Tweet}

N.B.: When citing this work, cite the original article.

Original Publication:

Ingrid Mignon and Andreas Rüdinger, The impact of systemic factors on the deployment of cooperative projects within renewable electricity production - An internatinoal comparison, 2016, Renewable and sustainable energy reviews, 65, pp. 478-488.

http://dx.doi.org/10.1016/j.rser.2016.07.026

Copyright: Elsevier

http://www.elsevier.com/

Postprint available at: Linköping University Electronic Press

http://urn.kb.se/resolve?urn=urn:nbn:se:liu:diva-131014

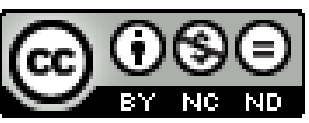




\title{
The impact of systemic factors on the deployment of cooperative projects within renewable electricity production-an international comparison
}

\author{
Ingrid Mignon (Corresponding author) \\ Linköping University, SE-581 83 Linköping (Sweden) \\ Tel: +4613281000 \\ Email Ingrid.mignon@liu.se \\ Andreas Rüdinger \\ Institute for Sustainable Development and Internal Relations (IDDRI) \\ 41, Rue du Four, 75006 Paris (France) \\ Email andreas.rudinger@iddri.org
}

\begin{abstract}
While cooperative organizations created with the aim to initiate, develop, and operate renewable electricity (RE) projects have received attention for their roles in the transition to a sustainable energy system, the disparities in the number of RE cooperative projects among countries suggest that institutional contexts may have an impact on their deployment. In order to systematically identify the systemic factors that impact their deployment, we use an established framework, considering the strengths and weaknesses in market structure, infrastructures, institutions, interactions, and capabilities. We compare the deployment context in Germany, France, and Sweden in order to understand which systemic factors have an impact and how they affect RE cooperative projects. Based on a review of the literature and qualitative interviews with experts in RE cooperatives, it appears that, although RE cooperative projects share some obstacles with most new entrants of RE, they are particularly exposed to a lack of financial infrastructure, a lack of knowledge and interactions, and problems related to a lack of regulatory frameworks facilitating their deployment. Results also show that systemic factors are complementary and dependent on each other: lowering one barrier lowers other barriers, and some obstacles strengthen other obstacles. Drawing on the comparison among Germany, France, and Sweden, we highlight some interesting practices that could be used in the coordination and alignment of systemic conditions for the deployment of RE cooperative projects.
\end{abstract}

Keywords:

Systemic obstacles, renewable electricity, energy transition, RE cooperatives, energy policy, Europe 


\section{Introduction}

Cooperatives formed by citizens with the objective of initiating, developing, and operating renewable electricity (RE) projects have received particular attention in the transition literature of the last few years [1-6]. Some authors and policymakers consider them to be a means to facilitate the energy transition, for instance, by creating local acceptance of wind power, by raising equity for the development of new RE plants, or by creating awareness of energy issues [e.g. 1,4,6]. Yet, the disparities among countries in the number of RE projects developed by cooperatives suggest that institutional contexts may have an impact on their expansion [e.g. 6,7,8].

Previous studies have identified a number of systemic factors that may affect the diffusion of technological innovations such as RE technologies [e.g. 9,10]. In particular, authors have shown that systemic strengths or weaknesses with regard to market structure, infrastructures, institutions, and interactions, as well as capabilities, are determinants for the deployment of RE technologies $[10,11]$. In this paper, we attempt to use this theoretical approach in order to understand the factors that affect the deployment of projects driven by a particular group of actors, i.e. RE cooperatives. This is motivated by the fact that few studies have analyzed the factors with an impact on RE cooperative expansion in a systematic way; thus, it is still hard to understand whether factors are shared by RE cooperatives across institutional frameworks or if they are country- or project-specific. Based on data collected through secondary sources, as well as qualitative interviews with experts on RE cooperatives in France, Germany, and Sweden, we compare these three countries, where clear disparities in the deployment of RE cooperative projects are accounted for.

The analysis of these data indicates that, while some challenges seem to affect the deployment of RE projects in general (e.g. the legitimacy of RE technologies), some problems are specific to $\mathrm{RE}$ cooperative projects (e.g. lack of regulative frameworks allowing their deployment and lack of a financing infrastructure). There are also problems that cooperatives share with other new RE project owners, but that affect them particularly (e.g. lack of legitimacy and market structure). Moreover, the results also show that systemic factors are complementary and dependent on each other: lowering one barrier lowers other barriers and some obstacles strengthen other obstacles.

This study sheds light on the impact that systemic factors have on the deployment of RE cooperative projects. It underlines the importance of policies encouraging their deployment, and it provides a foundation for policies targeting new entrants, in general, and RE cooperatives, in particular. Moreover, the comparison among countries provides interesting practices, which have positive impacts on the deployment of RE cooperative projects, which, potentially, can be replicated in other contexts.

In the following section, the previous literature on RE cooperative projects and its current gaps are first introduced, and the framework on systemic factors used in this paper is then presented. Section 4 describes the methodology chosen to collect and 
analyze data. The empirical data is then presented in Section 5 and analyzed in Section 6. The paper finally concludes in Section 7, with some implications for policies.

\section{The role of $\mathrm{RE}$ cooperative projects in the energy transition}

Despite many attempts to find a consensus on a definition of RE cooperatives, the concept is still vague and ambiguous, especially since what is legally included in the cooperative status often differs from country to country [12,13]. Nevertheless, authors share the understanding that RE cooperatives, no matter the context, imply some involvement of the public (e.g. the local community [e.g. 14] or the citizens of a region or country [e.g. 3]) in the decision-making (e.g. through democratic governance or through the ownership of the majority share of the projects [e.g. 3,15]) and a distribution of the benefits generated by the RE project in question $[12,16]$. In this paper, for the sake of clarity, we consider as RE cooperatives the citizen groups recognized as RE cooperatives in the country where their projects are developed, although we acknowledge that what the cooperative status exactly includes may differ among countries.

Over the last decade, RE cooperatives have received increased attention from scholars and policymakers. First, it has been emphasized that they may encourage the energy transition, for instance, by lowering some obstacles associated with the development of $\mathrm{RE}$ projects. Indeed, studies have shown that when local or non-local citizens take the initiative for their development, the local and public acceptance of RE projects is higher $[4,12]$. In many cases, such projects create a social acceptance of the construction of RE plants, because they involve the local inhabitants in the decision-making process $[6,17]$. Moreover, the public perceives them as having low profit-maximizing interests and as being willing to provide more benefits to local residents $[6,17]$. As a consequence, the prospects of getting a planning consent may be improved [18], which is a process that slows down the transition.

Second, some authors have shown that RE cooperatives may represent a means to finance the energy transition, since they may be an effective way to provide an additional equity source [19]. This is particularly relevant, because citizens (i.e. RE cooperative members) participating in such projects are less affected by risk, fluctuating profits, and unstable policies than venture capitalists $[3,8]$, especially in unstable economic contexts, such as during economic crises or recessions. In fact, they may even obtain loans at preferential conditions if key actors such as banks, support them $[2,19]$.

Third, studies have shown that RE cooperatives have the potential to create awareness of energy issues among their members and the local community where their projects are situated. Indeed, the participation of citizens in the development and the operationalization of RE projects is a way to spread knowledge, expertise, and enthusiasm for environmental consciousness and RE technologies [17,20]. This has been reported to lead to, for instance, an attitude change in the community or even a decrease in energy consumption among RE cooperative members [e.g. 5,6,17]. 
Finally, for some authors, RE cooperatives contribute to the democratization of the energy system [6,21]. From that perspective, a necessary condition for the energy transition to happen is the decentralization of the energy system, i.e. from the dominant control of large centralized utilities to citizen re-empowering through decentralized local and participative projects contributing to local energy autonomy $[13,22,23]$. By giving their members the ability to initiate and participate in decisions affecting their own energy system, RE cooperatives make this democratization possible and allow citizens to reclaim common goods [24].

Although the positive potential of RE cooperatives can hardly been questioned, there are large differences among countries with regard to the deployment of cooperative projects. Country-specific studies have reported many types of challenges that RE cooperatives face when developing new projects, such as conflicts among members or within the community [12], lack of professionalism [19], lack of legitimacy [17], lack of access to locations [6], unstable policy contexts [18,20,25], lack of experience [25], lack of access to capital $[6,19]$, lack of networks [5,25], and so forth. One remaining problem however, is the fact that few studies have analyzed obstacles in a systematic way; thus, it is still hard to understand whether the reported challenges are shared by $\mathrm{RE}$ cooperatives across institutional frameworks or if they are country- or project-specific. In an attempt to fill this gap, we propose to use a framework where systemic obstacles have systematically been studied, i.e. the technological innovation system literature.

\section{Systemic factors with an impact on the deployment of RE technologies}

The technological innovation system literature suggests that the development and diffusion of innovations (such as RE technologies) is determined by factors, i.e. strengths and weaknesses, at the socio-technical level of the system [e.g. 26,27-29]. According to these authors, innovation systems are composed of actors, networks, and institutions that interact and affect each other and that may block or encourage the diffusion of new technologies ${ }^{1}$ [30]. A better understanding of the potential obstacles at different system levels are crucial for policies aiming at facilitating the development and diffusion of innovations $[27,29]$. Based on a literature review of 50 articles studying the diffusion of RE technologies, Negro et al. [10] recently provided the following theoretical typology of systemic factors, with an impact on the deployment of RE technologies:

- The established market structure may have an organization and criteria to select innovations that can hinder the deployment of innovations. For instance, energy system incumbents may either want to prevent the apparition and the diffusion of RE innovations in order to protect their existing businesses, which are based on fossil fuels, or they may try to take ownership of the technological innovation to control its deployment, for example, by influencing the design of regulatory frameworks and

\footnotetext{
${ }^{1}$ It should be noted that while actors, networks and institutions that are endogenous of the innovation system may block or encourage its development, the diffusion of new technology may also be affected by factors, which are exogenous of the innovation system [Sandén \& Jonasson 2005].
} 
criteria for grid access in favor of larger projects and to the detriment of smaller emerging actors.

- Infrastructures may represent a problem if the basic physical and non-physical structures needed for the deployment of an innovation are lacking. For instance, the lack of storage capacities for solar power or the lack of access to the grid may hinder the deployment and use of RE technologies.

- Hard and soft institutions are the formal and informal rules and norms that exist within an institutional context. Formal rules, such as existing laws, regulations, standards, and informal norms and values, for instance public perceptions or acceptance of an innovation may hinder or slow down the deployment of innovations. RE technologies may, for instance, face unstable support systems, lack of legitimacy on the energy market, or local opposition to the development of new plants.

- If, within the system, interactions between actors (e.g. new entrants, governmental organizations, energy system incumbents) are either too strong or too weak, problems may occur that hinder or slow down the deployment of an innovation. For instance, in the case of RE technologies, if interactions between utilities (i.e. producing electricity with both fossil-fueled and RE technologies) are too strong, they may be reluctant to accept the apparition of new entrants and try to influence policy-makers in restricting their emergence. Likewise, interactions between adopters of the RE technologies may be too weak, which may lead to missed learning opportunities.

- The lack of capabilities, such as financial resources, knowledge or experience, among system actors may also affect the deployment of an innovation. In the case of RE technologies, actors may, for instance, lack the financial resources needed to invest, or they may lack the knowledge needed to implement the technologies.

Although these systemic factors have been developed in order to study the deployment of innovations, they provide a theoretical ground that may be used in order to systematically analyze the systemic conditions for the deployment of RE projects across countries. Therefore, in this paper, we apply Negro et al. [10]'s framework in order to study the systemic factors impacting the deployment of projects driven by RE cooperatives as an attempt to understand the impact of these factors on actors, rather than on technologies.

\section{Methodology}

4.1. A comparative study of three different institutional contexts

In order to understand the impact of systemic factors on the deployment of projects driven by RE cooperatives, we conducted a multiple case analysis of three countries: France, Germany, and Sweden. This method has been used in similar studies where 
institutional factors influencing the deployment of RE technologies have been assessed $[18,31]$, and it is considered to be particularly relevant in order to enhance the divergence between cases [32].

The choice of the three cases is justified by their comparability and by the interesting differences that characterize them. Indeed, based on European and national legislation, they have all committed themselves to ambitious objectives regarding the development of renewable energy in the power sector. France recently committed itself to increasing the share of RE from $15 \%$ in 2005 to $40 \%$ by 2030 , Germany from $10 \%$ in 2005 to $50 \%$ by 2030 , and Sweden from $50 \%$ in 2005 to $63 \%$ in 2020 . However, although they are part of the same European regulatory framework, the three countries rely on different policy instruments to support RE generation: Sweden has a tradable green certificate system (TGC); Germany recently moved from feed-in tariffs toward more market-based premium schemes; and France is currently using a mixture of different instruments, including feed-in tariffs, a market premium scheme (by 2016), and tenders.

Despite similar ambitions and the presence of support policies, the deployment of RE projects differs greatly between France, Sweden, and Germany, both in general and in terms of the number of projects developed and owned by new entrants (including RE cooperatives). For instance, whereas in Germany, RE cooperative projects represent almost $50 \%$ of total installed RE capacities, this type of projects is not as common in France and Sweden [33-36]. It has been suggested that the disparities in the deployment of RE cooperative projects may be explained by the general deployment of $\mathrm{RE}$ technologies in the respective countries [37]. However, the situation in Sweden, where the number of $\mathrm{RE}$ cooperative projects is low and the deployment of $\mathrm{RE}$ technology is high, suggests that there are other underlying factors. It is, therefore, relevant to study these cases in order to find out about the systemic factors that have an impact on the deployment on these projects.

\subsection{Data collection}

The case data were collected into two steps, through secondary data and interviews. We started by doing a content analysis of secondary data gathered from industry reports, policy documents, and analyses, as well as through the review of previous published scientific studies on the context of the development of RE cooperative projects and the associated challenges. Through this process, we were able to identified systemic factors, which affect the deployment of RE cooperative projects. However, the availability of secondary data and the state of country-specific scientific literature regarding cooperative organizations and their projects differ between the three countries, due, for instance, to different routines for public availability of reports and political analyses [5]. At this stage, it was therefore decided that we needed to complement the first data collection with additional data from interviews. This strategy gave us the opportunity to gather up-to-date information on the national context for RE cooperative project development and to triangulate the secondary data obtained during the first step of the data collection [38]. 
Interviews were conducted with experts in the field of RE production (Interviewees 1, 3, 4,6 , and 7) and with some of the initiators of the RE cooperative projects in different countries (Interviewees 2 and 5). Two interviews were conducted for Sweden (Interviewees 1 and 2), two for Germany (Interviewees 3 and 4), and three for France (Interviewees 5, 6 and 7). Experts in the field of RE production were considered as such because of their previous research on RE cooperatives in the context of their specific country. These are individuals that have followed the development of many $\mathrm{RE}$ cooperative projects and that have, over the years, gathered knowledge about the most common problems met by RE cooperatives and about the usual solutions chosen by RE cooperatives to solve these problems. In all cases, interviewees have developed guidelines for RE cooperative project development or published articles about common problems met by these organizations. Finally, in order to account for the individual perceptions of when a systemic challenge was considered as such or not and to take into consideration the systemic factors with a specific impact on RE cooperatives ${ }^{2}$, we also gathered the perspectives of actors that had gone (or that were going) through the process of developing RE cooperative projects through interviews with initiators of RE cooperative projects.

\subsection{Data analysis}

In order to systematically compare the systemic factors with an impact on the deployment of RE cooperative projects in the three countries, we analyzed the data based on predefined comparative factors previously classified by Negro et al. [10] in an extensive review of the literature on obstacles to the diffusion of RE technologies (as described in Section 3). In the categorization of the factors, we, therefore, looked at how market factors, hard and soft institutional factors, knowledge and physical infrastructure factors, interaction, and capability factors affected the deployment of RE cooperative projects. As a consequence of the focus of the analysis on the impact of factors on RE cooperatives, it appeared that some specific dimensions of factors were particularly relevant and that some factors were closely related with each other. As a consequence, subcategories of factors present in Negro et al. [10]'s framework became head categories (e.g. financial infrastructure) and some factors were gathered under a common head factors (e.g. knowledge and interactions).

\section{Results}

The results from the review of previous studies and from interviews show that the systemic context for RE cooperative projects differs from one country to another. In this section, we review the systemic factors with a potential impact on the deployment of RE cooperative projects in France, Germany, and Sweden.

\footnotetext{
${ }^{2}$ In addition to the cases when this had been addressed in the secondary data.
} 


\subsection{Market structure}

The three countries have different market structures, particularly with regard to the division of activities, i.e. generation, transmission, distribution, and retail, as well as the competition within them (see Table 1). France is characterized by the highest degree of monopolistic concentration, with the publicly owned utility, EDF, representing $90 \%$ of the total generation and a 92\% market share in retail. In contrast, the liberalization processes in Germany and Sweden have led to increased competition among electricity retailers and an unbundling of activities. In Sweden, Vattenfall was the only electricity retailer before the liberalization, but there are now more than 110 electricity retailers, of which about 30 offer electricity produced entirely from renewable sources. In Germany, about 1100 companies are active in the retail market, and the market for renewable power supplies has increased quickly since the nuclear accident of Fukushima, reaching 811 green electricity suppliers in 2014 [39].

In France, both the transmission and distribution grids are managed as monopolies by EDF's subsidiaries, RTE (Réseau de Transport d'Electricité) and ErDF (Electricité Réseau Distribution France). In Sweden, while the distribution grid is operated by 168 local operators, there is still a public monopoly on the operation of the transmission grid. In contrast, in Germany, the operation of both the transmission and distribution grids are shared among multiple operators.

Table 1: Overview of the electricity market-structure in France, Germany and Sweden (in 2013)

\begin{tabular}{|c|c|c|c|}
\hline & France & Germany & Sweden \\
\hline $\begin{array}{l}\text { Number of dominant } \\
\text { utilities ( }>15 \% \text { market share } \\
\text { in total generation) }\end{array}$ & 1 & 4 & 3 \\
\hline $\begin{array}{c}\text { Dominant utilities' } \\
\text { cumulative market share in } \\
\text { generation }\end{array}$ & $90 \%$ & $58 \%$ & $78 \%$ \\
\hline Transmission grid operation & $\begin{array}{l}\text { Centralized through } \\
\text { EDF's subsidiary RTE }\end{array}$ & $\begin{array}{c}4 \text { independent regional } \\
\text { operators }\end{array}$ & $\begin{array}{c}\text { Public monopoly } \\
\text { operated by Svenska } \\
\text { Kraftnät }\end{array}$ \\
\hline Distribution Grid operation & $\begin{array}{c}1 \text { main operator }(\text { ErDF }) \\
\text { owned by EDF }\end{array}$ & 900 local operators & 168 local operators \\
\hline $\begin{array}{c}\text { Number of retailing } \\
\text { companies }\end{array}$ & 18 & 1100 & 120 \\
\hline
\end{tabular}

As illustrated in Table 1, a few utilities dominate the RE market of the three studied countries. In Germany, utilities' initial lack of interest in participating in the development of new types of RE production ${ }^{3}$ from the appearance of RE technologies on

\footnotetext{
${ }^{3}$ Excluding hydropower
} 
the market has left a space for pro-RE actors to argue for favorable policies, which dominant utilities have criticized and advocated against [40-42].

In France, the dominant utilities (i.e. mainly EdF and GdF) are major voices in the policy debate [43], and they are also leading the RE deployment (even though RE only represents a minor share of their total business). Furthermore, they are the main funders and actors of the lobbying federation for RE in France.

In Sweden, two different behaviors have been observed among dominant utilities; while they have participated actively in the policy debate, advocating policy schemes in favor of their own business model, municipal energy companies, which can also be considered to be traditional actors in the Swedish energy market [34], have worked in favor of decentralized projects [Interviewee 1].

\subsection{Grid infrastructure}

Grid connection procedures, costs, and delays vary significantly, not only between countries, but also for different projects within each country [44]. In Germany, grid connection costs are generally considered low, since project developers only pay for the connection, not for additional reinforcement within the grid [45]. Moreover, due to the development of several thousand RES projects, permitting procedures are highly standardized and without excessive delays [46].

In France, the grid connection process is highly complex. Up to 20 authorities have to be contacted for the permitting procedure, and developers of the RE projects have to bear both direct connection costs and reinforcement costs at the next higher level of the grid [47]. Developers are entirely dependent on the will of the grid operators, who are not bound by legal obligations regarding the deadlines for grid connection, which sometimes results in significant delays [Interviewee 6].

In Sweden, the grid connection process itself is considered to be relatively simple [Interviewee 1]. However, there is a lack of transparency regarding the distribution of costs in cases when grid reinforcements are needed $[45,49]$. With the current practice, a new RE project has to carry the costs of its connection, no matter the voltage level or the potential societal benefits (e.g. if additional RE projects are built later on). This has led the government to order a commission of enquiry to look at alternative models for cost sharing, and there are discussions aimed at coordinating these costs and avoiding having one project carry the costs of other project connections [49].

\subsection{Financial infrastructure}

The financial infrastructure, i.e. the presence of a structure making it possible to secure financial capital (e.g. financial participation schemes, loans, and the willingness of banks to grant such loans), is crucial for the deployment of RE projects [e.g. 50]. In Germany, $\mathrm{RE}$ cooperative projects can rely on two complementary sources for debt capital: the

\footnotetext{
${ }^{4}$ At least for wind-, hydro-, biomass- and solar power projects. For offshore wind power projects, this process is much more complicated [48].
} 
public development bank $K f W$, which distributes preferential loans for all types of RES developers and ensures access to low-cost and long-term capital, and the network of local cooperative banks, which is a key supporter of cooperative energy projects [3].

In Sweden, because of banks' reluctance to grant loans for new entrants willing to develop wind power projects in the early 1990s, alternative ownership models were developed by RE cooperatives. Instead of contracting bank loans, the money raised in order to finance RE cooperative projects comes exclusively from selling shares to individual members [51]. The price of a share usually varies from 600 to 800 euros per share.

In France, none of the financial infrastructure existing in Germany and Sweden is available. Due to the lack of stability for RES support policies, banks have been reluctant to grant loans for RE projects. Moreover, alternative financial schemes, such as the one developed in Sweden, are legally very difficult to put in place. For instance, an approval from the financial market authority is required to raise equity through public offerings, and getting such an approval is a long administrative process [33].

\subsection{Soft institutions}

The legitimacy of RE cooperative projects in Germany has evolved over time. While public support for RE in general (and for RE cooperative projects specifically) has remained very strong over time, policymakers have rarely taken up the topic [Interviewee 3].

In contrast, French policies are overshadowed by the general lack of legitimacy of renewables in the field of electricity, given that most politicians argue that France already has a competitive and low-carbon power system, thanks to the historical development of nuclear energy [52,53]. However, the concept of citizen participation has recently specific attention in the recent national debate on the energy transition [Interviewee 5].

In Sweden, although new RE projects often meet local opposition, RE has general support in the public opinion [54]. Nevertheless, the national RE targets for 2020 and 2050 have been criticized for their lack of ambition [e.g. 55]. In 2013, seven years before 2020, Sweden had already reached its targets regarding the share of RE in the energy system (i.e. $51 \%$ by 2020 ).

\subsection{Hard institutions}

Overall, among the three countries, we found that two determinant types of hard institutions differed: the general energy policy frameworks for RE and the legal frameworks for RE cooperative projects.

In terms of transparency and stability of the general policy framework for renewable energy, Germany is often considered to be a best practice [42,56]. Indeed, despite regular policy changes to adjust for cost reduction and technology evolution, the overall framework has remained stable. Yet, with the 2014 reform of the renewable energy act (EEG), the policy scheme is evolving toward a market premium scheme (including 
mandatory direct marketing of electricity) and a planned generalization of tendering procedures [57].

Despite rather favorable support instruments (i.e. feed-in tariffs for most technologies), the French policy framework for RE is characterized by high uncertainty, administrative complexity, and disruptive "stop and go" policies, which, on several occasions, have had large consequences [58]. For instance, in 2010, PV feed-in tariff contracts were retroactively suspended, and in 2013, anti-wind power associations successfully challenged the legality of the existing feed-in tariff for wind power, which blocked the development of wind projects for almost one year. Moreover, administrative procedures for building permits and grid connections are considered to be very complex [59].

Sweden has used a tradable green certificate (TGC) system since 2003. Although this policy scheme is favorable toward RE development in general, it has received criticism for its inability to drive technological innovation (since only the most mature technologies are awarded support) [60] and for favoring market incumbents [61]. Because of its market-driven nature, it is considered to be less dependent on political uncertainties, but more dependent on electricity market prices [62,63]. Nevertheless, one aspect that the Swedish policy system often gets criticized for is the lack of transparency of its permit procedures, particularly for wind power $[64,65]$. Finally, the recent changes that have removed RE producers' exemption from consumption taxes on the electricity that they consume have received negative critiques [66].

With regard to the legal framework for RE cooperative projects, our study also accounts for differences between the three countries. In Germany, RE cooperative projects are strongly linked to the cooperative movement. As a legal form, the German cooperative (i.e. 'eingetragene Genossenschaft') is very flexible and helps to combine various groups of actors (citizens, municipalities, and private companies) under the same roof, while maintaining the possibility of continuously increasing the number of shareholders and capital [1].

In France, such a flexible legal form is absent. Moreover, due to the lack of a legal status of citizen initiatives, citizen groups who want to raise private equity to finance RE projects have to follow the same complex process as any other limited company, i.e. they have to obtain the authorization to perform a financial prospect from the financial market authority [33].

In Sweden, the main organizational status used for RE cooperative projects is the economic association status (i.e. 'ekonomisk förening')[67]. This status allows citizen groups to raise capital by selling shares to members, to own the RE plant by governing it democratically (through an elected board), and to use the electricity it produces. In contrast to other countries, where RE cooperative projects are producer associations, in Sweden, they are consumer associations [51]. In practice, this means that members are first charged for the electricity that they consume during the year (including costs related to TGC and taxes), and they can then subtract the electricity generated by their share(s) of the plant. It is, therefore, important that the members match their amount of 
shares with their yearly electricity consumption. Although members pay the electricity that they consume at a producer price (usually between $25 \%$ and $50 \%$ lower than a consumer price), there is no net debit of the electricity, which means that members still have to pay the energy tax for the electricity that they consume.

\subsection{Knowledge and interactions}

In Germany, following the example of the Energiewende Jetzt ("Energy transition now") network that provides training for the initiators of future projects in the region of Rhineland-Palatinate, networks have been developed in other regions. Likewise, there are many interactions between RE cooperative projects and other cooperative organizations, such as local cooperative banks and regional cooperative federations [Interviewee 4]. Finally, the federation for citizen energy (Bündnis Bürgerenergie e.V) represents a national platform for such projects.

In France, RE cooperative projects are very few and, as a consequence, so are the interactions between them [5]. Several initiatives from the national energy agency Ademe and from regional energy agencies (e.g. in Rhone-Alpes and Bretagne) are aimed at building networks and are currently emerging. However, they only provide limited technical support so far, and specific training opportunities for the founders of new RE cooperative projects are not yet available [33] .

In Sweden, despite a few courses offered by the wind power association and the information material available from the Swedish Energy Agency, systemized knowledge opportunities are rare [Interviewee 1]. Regional energy agencies exist ${ }^{5}$, but their mission is often directed more toward the support of electricity consumers than the support of electricity producers. In recent years, educational programs have been developed by universities, but this knowledge development is far from reaching the level needed for an extensive development of RE projects in Sweden [68,69]. Apart from that, informal networks of RE cooperative organizations exist, and a formal network portal is driven by the Swedish Energy Agency and the Swedish Wind Power Association.

\section{Analysis of the impact of systemic factors on the deployment of RE cooperative projects}

In this section, we analyze the impact that each of the systemic factors previously reviewed has on the deployment of RE cooperative projects in the countries selected for this study (see Table 2).

\footnotetext{
${ }^{5}$ E.g. East Sweden Energy Agency or the Energy Agency for Southeast Sweden
} 
Table 2: Overview of differences between countries

\begin{tabular}{|c|c|c|c|c|}
\hline & & France & Germany & Sweden \\
\hline \multicolumn{2}{|c|}{ Market structure } & $\begin{array}{l}\text { - High degree of } \\
\text { monopolistic } \\
\text { concentration of the } \\
\text { electricity retail. } \\
\text { - Transmission and } \\
\text { distribution activities } \\
\text { are monopolies. } \\
\text { - } 1 \text { main utility } \\
\text { dominates the market. }\end{array}$ & $\begin{array}{l}\text { - Competition among } \\
\text { electricity retailers. } \\
\text { - Unbundled generation, } \\
\text { transmission, retail } \\
\text { operated by multiple } \\
\text { operators. } \\
\text { - } 4 \text { main utilities } \\
\text { dominate the market. }\end{array}$ & $\begin{array}{l}\text { - Competition among } \\
\text { electricity retailers. } \\
\text { - Public monopoly on } \\
\text { the operation of the } \\
\text { transmission grid. } \\
\text { - Distribution operated } \\
\text { by multiple local } \\
\text { operators. } \\
\text { - } 3 \text { main utilities } \\
\text { dominate the market. }\end{array}$ \\
\hline \multicolumn{2}{|c|}{ Grid infrastructure } & $\begin{array}{l}\text { - Highly complex grid } \\
\text { connection process. } \\
\text { - RES developers bear } \\
\text { the costs of connection } \\
\text { and reinforcement } \\
\text { costs. } \\
\text { - RES developers are } \\
\text { dependent on grid } \\
\text { operators and } \\
\text { significant delays for } \\
\text { grid connection can be } \\
\text { observed. }\end{array}$ & $\begin{array}{l}\text { - Standardized } \\
\text { permitting procedures } \\
\text { with no excessive } \\
\text { delays. } \\
\text { - Grid connection costs } \\
\text { are considered low } \\
\text { (e.g. no additional } \\
\text { costs for the } \\
\text { reinforcement within } \\
\text { the grid). }\end{array}$ & $\begin{array}{l}\text { - Relatively simple grid } \\
\text { connection process } \\
\text { (except with offshore } \\
\text { wind). } \\
\text { - RES developers bear } \\
\text { the costs of the grid } \\
\text { connection. } \\
\text { - Lack of transparency } \\
\text { regarding distribution } \\
\text { of costs in case grid } \\
\text { reinforcements are } \\
\text { needed. }\end{array}$ \\
\hline \multicolumn{2}{|c|}{ Financial infrastructure } & $\begin{array}{l}\text { - Complex and difficult } \\
\text { process to raise capital: } \\
\text { banks are reluctant to } \\
\text { grant loan and equity } \\
\text { can only be raised } \\
\text { through public } \\
\text { offerings, which } \\
\text { require an approval of } \\
\text { the financial market } \\
\text { authority. }\end{array}$ & $\begin{array}{l}\text { Availability of two } \\
\text { complementary } \\
\text { sources for debt } \\
\text { capital: the public } \\
\text { development bank } \\
K f W \text { (preferential } \\
\text { loans for all types of } \\
\text { RES developers) and } \\
\text { the network of local } \\
\text { cooperative banks } \\
\text { (specific support for } \\
\text { RE cooperatives). }\end{array}$ & $\begin{array}{l}\text { - Capital is often raised } \\
\text { by selling shares of } \\
\text { the plants planning to } \\
\text { be developed to RE } \\
\text { cooperative members } \\
\text { instead of by } \\
\text { contracting bank } \\
\text { loans. }\end{array}$ \\
\hline \multicolumn{2}{|c|}{ Soft institutions } & $\begin{array}{l}\text { - Lack of political } \\
\text { legitimacy of RES due } \\
\text { to strong nuclear } \\
\text { support. } \\
\text { - } \\
\text { Increasing public } \\
\text { support in RES } \\
\text { projects and RE } \\
\text { cooperatives. }\end{array}$ & $\begin{array}{l}\text { - Strong public support } \\
\text { for RES projects in } \\
\text { general and for RE } \\
\text { cooperatives in } \\
\text { particular. } \\
\text { - No explicit political } \\
\text { support. }\end{array}$ & $\begin{array}{l}\text { - } \text { General public } \\
\text { support. } \\
\text { - } \text { RES projects often } \\
\text { meet local opposition. } \\
\text { - Lack of political } \\
\text { ambition with regard } \\
\text { to RES targets. }\end{array}$ \\
\hline $\begin{array}{c}\text { Hard } \\
\text { institutions }\end{array}$ & For $R E$ & $\begin{array}{l}\text { - Feed-in tariff } \\
\text { framework for most } \\
\text { RE technologies. } \\
\text { - Highly uncertain, } \\
\text { administratively } \\
\text { complex and "stop and } \\
\text { go" policy framework. } \\
\text { - Very complex } \\
\text { procedures for building } \\
\text { permits and grid } \\
\text { connections. }\end{array}$ & $\begin{array}{l}\text { - Stable feed-in tariff } \\
\text { framework (despite } \\
\text { regular adjustments of } \\
\text { the support to match } \\
\text { cost reduction and } \\
\text { technology evolution). } \\
\text { - Policy scheme moving } \\
\text { toward to market } \\
\text { premium scheme and a } \\
\text { generalization of the } \\
\text { tendering procedures. }\end{array}$ & $\begin{array}{l}\text { - Tradable green } \\
\text { certificate system (i.e. } \\
\text { market-based policy } \\
\text { instrument). } \\
\text { - Lack of transparency } \\
\text { of the permit } \\
\text { procedures (especially } \\
\text { for wind power). } \\
\text { - Recent changes on the } \\
\text { exemption for } \\
\text { consumption taxes on } \\
\text { RE producers' } \\
\text { consumed electricity. }\end{array}$ \\
\hline
\end{tabular}




\begin{tabular}{|c|c|c|c|}
\hline $\begin{array}{c}\text { For RE } \\
\text { cooperative } \\
\text { projects }\end{array}$ & $\begin{array}{l}\text { - Lack of legal status for } \\
\text { RE cooperatives. } \\
\text { - Complex process to } \\
\text { perform financial } \\
\text { prospects. }\end{array}$ & $\begin{array}{l}\text { RE cooperatives are } \\
\text { part of the larger } \\
\text { cooperative } \\
\text { organization } \\
\text { framework. } \\
\text { Very flexible legal } \\
\text { form for cooperative } \\
\text { organizations. }\end{array}$ & $\begin{array}{l}\text { Well-established } \\
\text { organizational status } \\
\text { allowing to raise } \\
\text { capital by selling } \\
\text { shares to members, to } \\
\text { govern the RE plants } \\
\text { democratically and to } \\
\text { use the electricity } \\
\text { produced. }\end{array}$ \\
\hline $\begin{array}{l}\text { Knowledge and } \\
\text { interactions }\end{array}$ & $\begin{array}{ll}\text { - } & \text { Very few RE } \\
\text { cooperative projects. } \\
\text { Emerging initiatives } \\
\text { aimed at forming RE } \\
\text { cooperative networks } \\
\text { from public agencies. } \\
\text { No training } \\
\text { opportunities } \\
\text { available for RE } \\
\text { cooperative initiators. }\end{array}$ & $\begin{array}{l}\text { Availability of } \\
\text { networks providing } \\
\text { training for the } \\
\text { initiators of future RE } \\
\text { cooperative projects. } \\
\text { - Availability of a } \\
\text { national platform for } \\
\text { RE cooperatives. } \\
\text { - Many interactions } \\
\text { between RE } \\
\text { cooperatives and other } \\
\text { cooperative } \\
\text { organizations. }\end{array}$ & $\begin{array}{l}\text { - Systemized training } \\
\text { opportunities are rare. } \\
\text { - Lack of higher } \\
\text { education programs } \\
\text { needed for an } \\
\text { extensive } \\
\text { development of RE } \\
\text { projects. } \\
\text { - Informal RE } \\
\text { cooperative networks } \\
\text { and a formal online } \\
\text { platform aimed at RE } \\
\text { cooperatives exist. } \\
\end{array}$ \\
\hline
\end{tabular}

\subsection{Market structure}

Although the three countries compared in this study present different characteristics with regard to the division of activities related to generation, transmission, distribution and retail of $\mathrm{RE}$, they all share the fact that their RE production market is dominated by a few strong dominant utilities (see Table 1). This has had a clear impact on the deployment of RE cooperative projects because utilities' political leverage and their implications in the policy debate on RE technologies and on the policy schemes. While in Germany, the lack of interest in RE technologies at the beginning of their market penetration left a space for new entrants such as RE cooperatives to argue for favorable policies [41,42], nowadays in all three studied countries, dominant utilities are advocating toward policies in favor of their own business model (e.g. market-based policies) or in favor of large market actors (i.e. at the cost of smaller actors) [40,41,70]. It is difficult to say how much this has influenced the RE policy schemes present in each country but it has clearly created dynamics in the political arena where new entrants, such as RE cooperatives, are constantly (directly or indirectly) pressured [51; Interviewee 1].

\subsection{Grid}

As illustrated in Table 2, the three countries present different degrees of challenges with regard to grid connections. While in Germany, the costs for grid connection are rather low, in Sweden and in France, the connection costs may represent an obstacle. The lack of transparency regarding costs is also problematic for such inexperienced actors that may need to make detailed financial forecasts for instance in order to get access to bank loans. Additionally, in France, the high level of complexity associated with the administrative process for grid connection may limit new RE project initiatives and increase both project costs and time delay for the production to start. 
Although these potential difficulties are similar for all RE projects, they have a higher impact on new entrants to RE production. Indeed, because of their lack of experience in the development of RE projects, new entrants are particularly affected by the complexity or the lack of transparency of the administrative process. Also, because of their lack of financial power and lack of project portfolios, they are very affected by a delay of grid connection (corresponding to a delay in profit generation) or by high connection costs. Nevertheless, nothing suggests that RE cooperative projects are specifically affected by this challenge in comparison with projects developed by other new entrants.

\subsection{Financial infrastructure}

In Germany, the availability of a favorable financial infrastructure has led project developers to consider RE cooperatives to be an opportunity to facilitate the equity raise for RE projects. In Sweden, the fact that the amount of shares that can be bought by members has to match their electricity consumption is considered to be a limitation [Interviewee 2]. This may indeed lead some citizens to choose alternative investment forms (e.g. participation in RE projects developed by professional project developers) or alternative investments outside RE [71; Interviewee 2]. In France, the lack of financial infrastructure affects all types of new entrants, but it can be considered to hinder RE cooperatives even more, since most banks consider their projects to be too complex and risky [33]. In order to cope with this challenge, existing initiatives have resorted to innovative funding strategies, involving local investment clubs (i.e. 'CIGALES') and interwoven legal forms to circumvent regulatory barriers. Nevertheless, since these structures are very complex and often legally in a grey area, the lack of financial infrastructure is still considered to be one of the main barriers to the deployment of RE cooperative projects in France [33].

\subsection{Soft institutions}

Soft institutions impact the legitimacy of RE cooperatives at different levels: the political level, the public level, and the local level. Although in Germany and Sweden, the public legitimacy in RE cooperatives is high, policymakers are more restrictive in showing their support. Yet, the French and German examples show that political legitimacy can be a determinant for the policy context of RE cooperative projects. In Germany, despite a high public legitimacy context, without a clear political legitimacy, there is a risk that new policies with a negative impact will emerge. In contrast, in France, despite a low public legitimacy context, political legitimacy may switch and result in favorable policies.

\subsection{Hard institutions}

While the stable general RE policy scheme in place in Germany until 2014 has created a high degree of trust and low risks, which have led to an exponential growth in RE, the recent policy changes toward a market premium scheme represent a significant uncertainty for most RE projects, no matter whether they are developed by dominant utilities, new entrants, or RE cooperatives [72]. Nevertheless, the generalization of the tendering scheme represents a higher risk for smaller actors, such as many new 
entrants, who may not have the resources to compete for RE projects against professional developers $[73,74]$.

In France, the instability of the policy system has also led to the loss and delay of numerous projects [75]. Moreover, the complexity of administrative procedures for building permits and grid connections induces further delays; according to project developers active in both countries, it takes up to eight years to develop a wind power project in France, compared to three years in Germany [76; Interviewee 7] . These additional delays and complexities constitute a major barrier for projects developed by small actors and, particularly, for RE cooperative projects, taking into account the induced financial needs and the risk that citizens might redraw their capital if the project is not realized in time [33; Interviewee 5].

In Sweden, the policy context and the electricity prices have led to market opportunities, resulting in a large increase of RE projects [34]. Nevertheless, the administrative system is often perceived as complex, long, and sometimes unfair [77], particularly for small and inexperienced RE actors, such as RE cooperatives.

With regard to the legal framework as it applies to RE cooperative projects, the German example shows that despite the positive impact of the presence of a flexible status and of favorable public support, without a clear political support policy uncertainties may occur, which may have a dramatic impact on RE cooperative project deployment [78]. During the reform of the renewable energy act in 2014, specific measures to adapt the future policy framework to the requirements of RE cooperative projects have not received significant support [Interviewee 3] and after a spectacular takeoff in recent years, with the number of newly created RE cooperatives reaching 194 in 2011, numbers fell down to 29 in 2014.

In Sweden, similar dynamics were observed after changes were made to the tax exemption on the electricity consumption of internally produced electricity in 2011 . Indeed, the number of new RE cooperative projects have stagnated since 2011 [51].

Finally, in France, the lack of status for RE cooperative projects has a direct impact on their deployment, since it leads to very complex legal constructions, with the need of combining various forms and companies in order to link up different types of actors and to circumvent the lengthy and complex process of obtaining a visa from the financial market authority in order to raise private equity [33]. Nevertheless, the recent national debate on the energy transition attached high importance to the concept of citizen participation, leading to several favorable measures in that regard [Interviewee 5]. For instance, the new law on the energy transition should clarify the status of RE cooperative projects and facilitate the capital raising process needed for such projects [Interviewees 5, 7].

\subsection{Knowledge and interactions}

Since the members of RE cooperative projects are rarely professionals of RE project development, they generally show a lack of capabilities (e.g. technical knowledge, 
financial models, and communication skills) on the individual level, which reinforces the importance of knowledge infrastructure (i.e. knowledge organizations or formal networks) and interactions with other actors (e.g. informal networks) to overcome these barriers.

In Germany, the deployment of RE cooperative projects has benefited from a dense network of partnering institutions (both private and public) [Interviewee 3]. For instance, it has provided additional technical capacities, e.g. through the creation of platforms to improve the exchange of experiences, and it has opened up the possibility of common political leverage. Thanks to the interactions with other cooperative organizations, RE cooperatives receive additional support for the creation of new projects, such as additional technical and financial assistance. Finally, the federation for citizen energy facilitates the exchange of experiences and intensifies political lobbying activities on the national level.

In France, the limited amount of RE cooperatives does not provide the development support or the political leverage needed at this stage. While some regions have provided financial and technical support for specific projects, the structuration of more comprehensive networks for technical assistance remains hesitant and mostly relies on the capacity of the different RE cooperative projects to federate themselves in the absence of institutionalized political support [33].

In Sweden, although forums exist for RE cooperative projects, they are far from being as institutionalized and integrated as those in Germany. In general, RE cooperatives handle the complexity of RE project development by hiring the services of private consultants or by relying on their networks [71].

\section{Conclusion and policy implications}

The results of this study show, first, that the systemic obstacles identified by Negro et al. [10] have different levels of impact on RE cooperative projects. As presented in Section 6, some structural aspects, such as market structure, grid infrastructure, or some soft and hard institutions, affect projects that are developed and operated by all types of new entrants. In that context, RE cooperatives are no different than other new entrants. Compared with market incumbents, new entrants often lack the required capabilities for the development of RE projects, such as knowledge and experience, market and political contacts, or financial resources. This explains why these obstacles particularly impact them.

However, our study also shows that RE cooperative projects are specifically affected by a lack of financial infrastructure, a lack of knowledge infrastructure, and a hard institutional context that hinders their deployment. The comparison among countries suggests that the main factor behind these specific challenges is the lack of institutionalization of the RE cooperatives leading these projects. Indeed, in France, for instance, the RE cooperatives sometimes lack the status and structure needed to raise 
capital or, as in the case of France and Sweden, they lack the networks and the legal framework needed to share knowledge and get political leverage.

Second, while some systemic factors affect all types of new entrants (including RE cooperatives), RE cooperatives' ability to find unexpected solutions (for instance, for the financing of projects, as illustrated by the development of local investment clubs in France) or to organize themselves in associations or networks (as illustrated in the example of Germany) suggests that they are characterized by driving forces that allow them to handle challenges. While this aspect has not received much attention in previous studies of the role of RE cooperatives for energy transition (as described in Section 2), we claim that this may be one of the strengths of RE cooperative projects and that it should be considered in future research.

Third, when considering an actor perspective on systemic factors impacting the deployment of RE cooperative projects, we found some interactions and complementarities among these factors. For instance, in France, the lack of legitimacy of both RE technologies and RE cooperatives has triggered additional new barriers with regard to policy instability, conditions for grid access, and regulations about local capital investments. In contrast, the example of Germany shows how interactions between RE cooperatives can help reduce obstacles related to a lack of knowledge infrastructure and can create political leverage.

Finally, the results of the study show the extent to which systemic factors are directly or indirectly affected by policy choices. For instance, in Germany, the current process of moving toward more market-based support schemes for RE (market premium and technology-neutral tenders) has had a clear impact on slowing down the deployment of RE cooperative projects since 2014. This shows that even well-institutionalized practices cannot be taken for granted and illustrates how dependent these RE cooperatives remain on the existence of a regulatory framework that takes into account their specific characteristics.

If policymakers want to encourage the deployment of RE cooperative projects, the findings of this paper provide a starting point to reduce obstacles and to develop support specifically targeting these types of projects. To start with, policy-makers may choose to either target obstacles that are specifically affecting RE cooperatives or to target obstacles that affect all types of new entrants. Policies focusing on obstacles that are specific to RE cooperatives may be created rather quickly because they affect only one actor type. In contrast, focusing on obstacles that are common to all new entrants has the potential to affect the whole RE production market. As such, this strategy may be the first step towards a faster diffusion of RE technology, which may lead to a faster energy system transition, but it may also create substantial opposition from energy system incumbents such as utilities. This step may therefore have reverse effects if utilities, thanks to their political leverage, take that opportunity to advocate against any type of policies aimed at supporting new entrants, as it has happened in the past for instance in France and in Germany. 
As the results of this paper indicate, there is a large potential for the design of new regulatory frameworks to encourage and facilitate the deployment of RE cooperative projects. In that regard, the comparison among Germany, France, and Sweden provides interesting solutions that could be used as best practices by policymakers or by RE cooperatives willing to develop RE projects. For instance, regarding financial infrastructures, the participating model used in Sweden and in Germany may be generalized. Yet, for that model to be applied, it is important to develop a regulatory framework in which this is not only allowed, but also routinized. Here again, policymakers may find inspiration from countries where a diversity of legal statuses for $\mathrm{RE}$ cooperative projects is in place. Another learning from the country comparison is that while innovative actors can overcome some of the barriers on their own (e.g. in France), a coherent and supportive framework is needed to foster large-scale diffusion, as observed in Germany. The fact that Germany is on the way of making reforms, which may drastically limit the opportunities of deployment for projects developed by any type of new entrants, also stresses the fact that a well-functioning institutional context can never be taken for granted. Instead, it requires constant vigilance from new entrant coalitions and a clear understanding on the impact of changes on new entrants from policy-makers.

\section{Acknowledgments}

The authors are grateful for the funding of the Swedish Energy Agency within the frame of the Strategic Energy System Research program (Project 40642-1).

\section{References}

[1] Yildiz Ö, Rommel J, Debor S, Holstenkamp L, Mey F, Müller JR, et al. Renewable energy cooperatives as gatekeepers or facilitators? Recent developments in Germany and a multidisciplinary research agenda. Energy Res Soc Sci 2015;6:5973. doi:10.1016/j.erss.2014.12.001.

[2] Dóci G, Vasileiadou E, Petersen AC. Exploring the transition potential of renewable energy communities. Futures 2015.

[3] Yildiz Ö. Financing renewable energy infrastructures via financial citizen participation-The case of Germany. Renew Energy 2014;68:677-85.

[4] Boon FP, Dieperink C. Local civil society based renewable energy organisations in the Netherlands: Exploring the factors that stimulate their emergence and development. Energy Policy 2014;69:297-307.

[5] Yalçın-Riollet M, Garabuau-Moussaoui I, Szuba M. Energy autonomy in Le Mené: A French case of grassroots innovation. Energy Policy 2014;69:347-55. doi:10.1016/j.enpol.2014.02.016.

[6] Huybrechts B, Mertens S. The relevance of the cooperative model in the field of renewable energy. Ann Public Coop Econ 2014;85:193-212. doi:10.1111/apce.12038.

[7] Seyfang G, Park JJ, Smith A. A thousand flowers blooming? An examination of community energy in the UK. Energy Policy 2013;61:977-89. 
[8] Agterbosch S, Vermeulen W, Glasbergen P. Implementation of wind energy in the Netherlands: the importance of the social-institutional setting. Energy Policy 2004;32:2049-66. doi:10.1016/s0301-4215(03)00180-0.

[9] Jacobsson S, Johnson A. The diffusion of renewable energy technology: an analytical framework and key issues for research. Energy Policy 2000;28:625-40. doi:10.1016/s0301-4215(00)00041-0.

[10] Negro SO, Alkemade F, Hekkert MP. Why does renewable energy diffuse so slowly? A review of innovation system problems. Renew Sustain Energy Rev 2012;16:3836-46. doi:10.1016/j.rser.2012.03.043.

[11] Painuly JP. Barriers to renewable energy penetration; a framework for analysis. Renew Energy 2001;24:73-89. doi:10.1016/S0960-1481(00)00186-5.

[12] Walker G, Devine-Wright P, Hunter S, High H, Evans B. Trust and community: Exploring the meanings, contexts and dynamics of community renewable energy. Energy Policy 2010;38:2655-63.

[13] Kunze C, Becker S. Collective ownership in renewable energy and opportunities for sustainable degrowth. Sustain Sci 2015:1-13.

[14] Dunning J, Turner A. Community-owned wind farms-aspirations, suspicions and reality. Power UK 2005;131:42-5.

[15] Hoffman SM, High-Pippert A. Community energy: a social architecture for an alternative energy future. Bull Sci Technol Soc 2005;25:387-401.

[16] Walker G, Devine-Wright P. Community renewable energy: What should it mean? Energy Policy 2008;36:497-500. doi:10.1016/j.enpol.2007.10.019.

[17] Walker G, Hunter S, Devine-Wright P, Evans B, Fay H. Harnessing community energies: explaining and evaluating community-based localism in renewable energy policy in the UK. Glob Environ Polit 2007;7:64-82.

[18] Toke D, Breukers S, Wolsink M. Wind power deployment outcomes: How can we account for the differences? Renew Sustain Energy Rev 2008;12:1129-47. doi:10.1016/j.rser.2006.10.021.

[19] Enzensberger N, Fichtner W, Rentz O. Evolution of local citizen participation schemes in the German wind market. Int J Glob Energy Issues 2003;20:191-207.

[20] Toke D. Community wind power in Europe and in the UK. Wind Eng 2005;29:3018. doi:10.1260/030952405774354886.

[21] Schneider F, Kallis G, Martinez-Alier J. Crisis or opportunity? Economic degrowth for social equity and ecological sustainability. Introduction to this special issue. J Clean Prod 2010;18:511-8. doi:10.1016/j.jclepro.2010.01.014.

[22] Labussière 0, Nadaï A. Wind Power Landscapes in France: Landscape and Energy Decentralization. Renew. Energ. Eur. Landsc., Springer; 2015, p. 81-93.

[23] Cumbers A. Reclaiming public ownership: Making space for economic democracy. London, UK: Zed; 2012.

[24] Moss T, Becker S, Naumann M. Whose energy transition is it, anyway? Organisation and ownership of the Energiewende in villages, cities and regions. Local Environ 2014:1-17.

[25] Walker G. What are the barriers and incentives for community-owned means of energy production and use? Energy Policy 2008;36:4401-5.

[26] Johnson A. Functions in innovation system approaches, 2001.

[27] Bergek A, Jacobsson S, Hekkert M, Smith K. Functionality of innovation systems as a rationale for and guide to innovation policy. In: Smits R, Kuhlmann S, Shapira P, editors. Theory Pract. Innov. Policy - Int. Res. Handb., Cheltenham (UK) and Northampton, MA: Edward Elgar Publishing; 2010, p. 469. 
[28] Hekkert MP, Suurs RAA, Negro SO, Kuhlmann S, Smits REHM. Functions of innovation systems: A new approach for analysing technological change. Technol Forecast Soc Change 2007;74:413-32. doi:10.1016/j.techfore.2006.03.002.

[29] Bergek A, Jacobsson S, Carlsson B, Lindmark S, Rickne A. Analyzing the functional dynamics of technological innovation systems: A scheme of analysis. Res Policy 2008;37:407-29.

[30] Carlsson B, Stankiewicz R. On the nature, function and composition of technological systems. J Evol Econ 1991;1:93-118. doi:10.1007/bf01224915.

[31] Breukers S, Wolsink M. Wind power implementation in changing institutional landscapes: An international comparison. Energy Policy 2007;35:2737-50. doi:10.1016/j.enpol.2006.12.004.

[32] Eisenhardt KM, Graebner ME. Theory building from cases: opportunities and challenges. Acad Manage J 2007;50:25-32.

[33] Poize N, Rüdinger A. Projets citoyens pour la production d'énergie renouvelable : une comparaison France Allemagne. Paris, France: Iddri; 2014.

[34] Bergek A, Mignon I, Sundberg G. Who invests in renewable electricity production? Empirical evidence and suggestions for further research. Energy Policy 2013:56881.

[35] Bergek, Mignon I. Nya investerare i förnybar elproduktion: motiv, investeringskriterier och policykonsekvenser (NyEL). Energimyndigheten: Linköpings Universitet; 2014.

[36] Nadaï A, Debourdeau A, Dobigny L. Communautés énergétiques, état des analyses et enjeu. Nogent-Sur-Marne: CIRED; 2012.

[37] Haas R, Resch G, Panzer C, Busch S, Ragwitz M, Held A. Efficiency and effectiveness of promotion systems for electricity generation from renewable energy sources Lessons from EU countries. Energy 2011;36:2186-93. doi:10.1016/j.energy.2010.06.028.

[38] Miles MB, Huberman AM. Qualitative data analysis: An expanded sourcebook. Sage; 1994.

[39] Reichmuth M. Marktanalyse Ökostrom: Endbericht. Berlin: 2014.

[40] Lauber V, Sarasini S. The response of incumbent utilities to the challenge of renewable energy. Syst Perspect Renew Energy 2014.

[41] Stenzel T, Frenzel A. Regulating technological change-The strategic reactions of utility companies towards subsidy policies in the German, Spanish and UK electricity markets. Energy Policy 2008;36:2645-57. doi:10.1016/j.enpol.2008.03.007.

[42] Jacobsson S, Lauber V. The politics and policy of energy system transformationexplaining the German diffusion of renewable energy technology. Energy Policy 2006;34:256-76. doi:10.1016/j.enpol.2004.08.029.

[43] Bauby P, Varone F. Europeanization of the French electricity policy: four paradoxes. J Eur Public Policy 2007;14:1048-60.

[44] Zane EB, Brückmann R, Bauknecht D, Jirouš F, Piria R, Trennepohl N, et al. Integration of electricity from renewables to the electricity grid and to the electricity market. 2012.

[45] Swider DJ, Beurskens L, Davidson S, Twidell J, Pyrko J, Prüggler W, et al. Conditions and costs for renewables electricity grid connection: Examples in Europe. Renew Energy 2008;33:1832-42. doi:10.1016/j.renene.2007.11.005.

[46] Brückmann R. National Report: Germany. Integr. Electr. Renew. Electr. Grid Electr. Mark. RES-Integr., Eclarean; 2011. 
[47] Spitzley J-B. National report: France. Integr. Electr. Renew. Electr. Grid Electr. Mark. RES-Integr., Eclareon; 2011.

[48] Jacobsson S, Karltorp K. Mechanisms blocking the dynamics of the European offshore wind energy innovation system-Challenges for policy intervention. Energy Policy 2013;63:1182-95.

[49] Swedish Energy Markets Inspectorate. Tröskeleffekter och förnybar energi. Eskilstuna: 2015.

[50] Kemfert C, Schäfer D. Financing the energy transition in times of financial market instability. DIW Econ Bull 2012;2:3-13.

[51] Wizelius T. Windpower Ownership in Sweden: Business Models and Motives. Routledge; 2014.

[52] Conseil National du Débat. Synthèse du débat national sur la transition énergétique. Paris: Ministère de l'Environnement, de l'Énergie et de la Mer; 2013.

[53] Topçu S. La France nucléaire. L’art de gouverner une technologie contestée. Seuil; 2013.

[54] Ek K. Public and private attitudes towards "green" electricity: the case of Swedish wind power. Energy Policy 2005;33:1677-89.

[55] Bryntse G, Jönsson B, Wijkman A. 100 procent förnybart ett möjligt energimål. Sven Dagbladet 2014.

[56] Verbruggen A, Lauber V. Assessing the performance of renewable electricity support instruments. Energy Policy 2012;45:635-44.

[57] Bundestag G. Act on the Development of Renewable Energy Sources (RES Act 2014). 2014.

[58] Nadaï A. "Planning","siting" and the local acceptance of wind power: Some lessons from the French case. Energy Policy 2007;35:2715-26.

[59] Syndicat des Energies Renouvelables. 30 measures de simplification administrative proposées par le Syndicat des Energies Renouvelables. 2014.

[60] Bergek A, Jacobsson S. Are tradable green certificates a cost-efficient policy driving technical change or a rent-generating machine? Lessons from Sweden 2003-2008. Energy Policy 2010;38:1255-71. doi:10.1016/j.enpol.2009.11.001.

[61] Jacobsson S, Bergek A, Finon D, Lauber V, Mitchell C, Toke D, et al. EU renewable energy support policy: Faith or facts? Energy Policy 2009;37:2143-6. doi:10.1016/j.enpol.2009.02.043.

[62] Batlle C, Pérez-Arriaga IJ, Zambrano-Barragán P. Regulatory design for RES-E support mechanisms: Learning curves, market structure, and burden-sharing. Energy Policy 2012;41:212-20. doi:10.1016/j.enpol.2011.10.039.

[63] Klessmann C, Nabe C, Burges K. Pros and cons of exposing renewables to electricity market risks-A comparison of the market integration approaches in Germany, Spain, and the UK. Energy Policy 2008;36:3646-61.

[64] Bergek A. Levelling the playing field? The influence of national wind power planning instruments on conflicts of interests in a Swedish county. Energy Policy 2010;38:2357-69. doi:10.1016/j.enpol.2009.12.023.

[65] Khan J. Wind power planning in three Swedish municipalities. J Environ Plan Manag 2003;46:563-81. doi:10.1080/0964056032000133161.

[66] Bolund P. Uttagsskatt på el från vindkraftverk. Sveriges Riksdag; 2008.

[67] Wizelius T. Vindkraft tillsammans - Handbok för vindkooperativ. Vindform; 2012.

[68] Karltorp K. Scaling up renewable energy technologies -The role of resource mobilisation in the growth of technological innovation systems. Chalmers University of Technology; 2014. 
[69] Karltorp K, Jacobsson S, Sandén BA. The need for financial and human resources the case of offshore wind power. Syst. Perspect. Renew. Power 2014, Gothenbourg: Charmers University of Technology; 2014.

[70] Lauber V, Schenner E. The struggle over support schemes for renewable electricity in the European Union: a discursive-institutionalist analysis. Environ Polit 2011;20:508-27.

[71] Mignon I. Entering renewable electricity production - An actor perspective. Linköping University, 2014.

[72] Pahle M, Schweizerhof $H$. A risk perspective on market integration and the reform of support of renewables in Germany 2015.

[73] Degenhart H, Nestle U. Marktrealität von Bürgerenergie und mögliche Auswirkungen von regulatorischen Eingriffen 2014.

[74] Gawel E, Purkus A. Promoting the market and system integration of renewable energies through premium schemes-a case study of the German market premium. Energy Policy 2013;61:599-609.

[75] Quirion P. Quel mode de soutien pour les énergies renouvelables électriques? 2015.

[76] Edlich S. Durée et coûts de développement des projets éoliens, http://enree.com/fileadmin/user_upload/Downloads/Konferenzen/EWEA_2012/EWEA_Vor trag_4_120418_Sophie_Edlich.pdf; 2012.

[77] Åstrand K, Neij L. An assessment of governmental wind power programmes in Sweden-using a systems approach. Energy Policy 2006;34:277-96. doi:10.1016/j.enpol.2004.08.036.

[78] Müller JR, Holstenkamp L. Zum Stand von Energiegenossenschaften in Deutschland 2015. 